\title{
A Media Discourse of Broadband Policy in a Developing Country Context
}

\author{
Johannes Vergeer, Wallace Chigona, and Andile Simphiwe Metfula \\ Department of Information Systems, University of Cape Town, Cape Town, South Africa \\ \{Johannes.Vergeer, Wallace.Chigona, Andile.Metfula\} @uct.ac.za
}

\begin{abstract}
Abstract: The formation of bodies like the World Summit on the Information Society (WSIS) and the incorporation of Information and Communication Technologies (ICTs) in the Millennium Development Goals (MDGs) have given birth to the importance of connectivity, thus putting the Internet on the national agenda of every nation in the world. Countries (especially developing nations) have started drafting their own broadband policies so as to be able to 'quickly' provide Internet access to 'all' their citizens and to be able to 'immediately' start 'reaping' the fruits provided by broadband. This paper, therefore, looks at this process in the Republic of South Africa - that is, the discourses around the formulation of the National Broadband Policy - in order to uncover possible distortions and misconceptions. Moreover, it also looks at the interactions that existed amongst the actors that were involved or were supposed to be involved in the policyformulation process. This is done by using Habermas' Critical Discourse Analysis (CDA).
\end{abstract}

Keywords: Broadband Policy.

\section{Introduction}

\subsection{Background}

Nowadays the importance of the Internet, especially Broadband Internet, cannot be over-emphasised. Governments see it as a catalyst to speed up service delivery; capitalists see it as a dynamic business tool; educators see it as a new knowledge provider; youngsters see it as a new form of expressing dissent and entertainment. In his budget speech to Parliament on the 20th of April 2010, the then Minister of Communications, Siphiwe Nyanda made a statement that by 2019 South Africans would enjoy universal access to broadband. This was a bold statement considering the current ICT penetration rate in the country. Benefits of the access, Nyanda stated, would include the provision of multimedia, e-governance and economic growth (Nyanda, 2010). The Broadband Policy - which would in turn bring all these benefits into fruition - was finalised on the 13th of July 2010 after parliamentary deliberations and, most importantly, supposed public consultations. Considering the importance of the policy and the dismal outcomes of other ICT policies in the developing countries, it is of academic interest to investigate the likelihood of the policy succeeding. 
As the formulation of a Broadband Policy was highly topical at this time, both locally and internationally, it is important to note concerns raised about the generally poor policy outcomes of Information and Communication Technology (ICT) in Africa. Gillwald (2010) attributes the poor outcomes to the paucity of critical research that recognises the political dimensions of policy reform and economic regulation.

\subsection{Media Discourse and the Public Sphere}

To contribute towards this understanding, this study traces the South African media reporting (both print and electronic) and the response of civil society (often via dedicated web-based environments) on the rhetoric of 'Broadband' and, in particular, focuses on its role during the South African Broadband Policy formulation process. Consequently, the theoretical foundation used in this paper is Habermas' Theory of Communicative Action (Habermas, 1984), which focuses on the impact and implications of a discourse.

Habermas posits that the conceptual category of the public sphere is essential to the evolution and maintenance of a democratic society. This public sphere, he asserts, consists of politicians and their political parties, lobbyists, non-governmental organisations (NGOs) and other pressure groups, as well as mass media professionals with their networks of electronic and print media. The public sphere actors often compete to set the agenda on crucial public issues like policy formulation (Mills, 2009). Norton-Griffiths (2010) noted that this competition culminates in the adoption of minority views of the powerful, thus defeating the whole purpose of a democratic society and process. The media, as part of the public sphere, plays a central role in shaping public discourses (Cukier, Ngwenyama, Bauer \& Middleton, 2009b). It provides a primary source of information (Melody, 2006). It is also a vehicle by which civil society obtains information and becomes involved in the political process. The media are not only consumed by the public, but also by politicians who use the media to learn of the needs of the people and to influence public opinion. Thus, in many ways, the media affects the political and more importantly, the policy process (Cooper \& Johnson, 2007). Figure 1 further illustrates this.

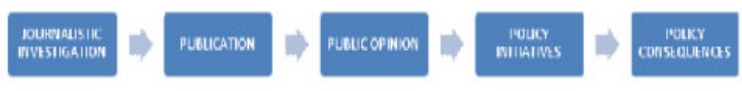

Fig. 1. The Media und the Policy Process (Coopers \& Johnson, 2007)

Therefore, as they (the media) have an influence on what we think about and how we think about it, it is important to highlight distortions in these discourses (Chigona \& Chigona, 2008). The identification of distorted media discourses, especially those dealing with policy formulation, is important, as the possibility exists for political elites and privileged groups to deflect citizens' individual and collective interests (Guardino, 2009).

\subsection{Research Aims, Claims, Questions and Approach}

This paper, therefore, seeks to understand the workings of the public discourse surrounding the South African Broadband Policy debate, thus facilitating a better 
understanding of the factors influencing the debate about the availability and adoption of broadband technologies and services in the South African context. Its main intention is to answer the call made by Gillwald (2010) to contribute towards indigenous research that engages in the ICT policy space. This research aims specifically at understanding the interplay between various institutions and the roles they play, particularly in the telecommunications arena. Thompson \& Walsham (2010) once called upon researchers in Information Systems to critically look at national and international policies, so as to be able to make sound and meaningful contributions to individual national ICT policies. In the same vein, Delano (2009) noted that there was a need for more research so that more rational ICT policies and strategies are realised and are efficiently put to use to end the existing digital divides in the world. The synchronisation of regional and international ICT policies with local ones is imperative; local initiatives and policies should not be affected by foreign ones, but should be the other way around (McBride \& Stahl, 2009). The research question answered by this paper is:

What distortions and misconceptions does media discourse have about the South African Broadband Policy?

It answers this question by using Habermas' Theory of Communicative Action (TCA) to analyse the discourse that surrounded the formulation of the Broadband Policy in South Africa.

\subsection{Structure of the Paper}

The structure of this paper is as follows:

- The following section talks about the background of broadband.

- Section three looks at the broadband environment in South Africa.

- Section four is the theoretical framework.

- Section five is the research methodology.

- Section six looks at the findings.

- Section seven is the discussion of the findings.

- Section eight makes some conclusions and recommendations.

\section{Broadband Background}

The term 'broadband' has no universally accepted definition, but generally refers to high bandwidth Internet access (Van den Broeck \& Lievens, 2007). The Broadband Commission for Digital Development defines it as a cluster of concepts ranging from instantaneous updates to simultaneous provision of services (The Broadband Commission, 2010a).

\subsection{Overview of Broadband}

The discussion around broadband should however move beyond the merely technical aspects of access and speed. Attention also has to be directed to the social dimensions of having broadband connectivity, considering the potential benefits to users and society as a whole. In many respects the technology is not as important as what can be 
accomplished by using it (Van den Broeck \& Lievens, 2007). Kim, Kelly \& Raja (2010) see broadband as an ecosystem (see Figure 2), consisting of networks, services carried on these networks, the applications they deliver and the users making use of these.

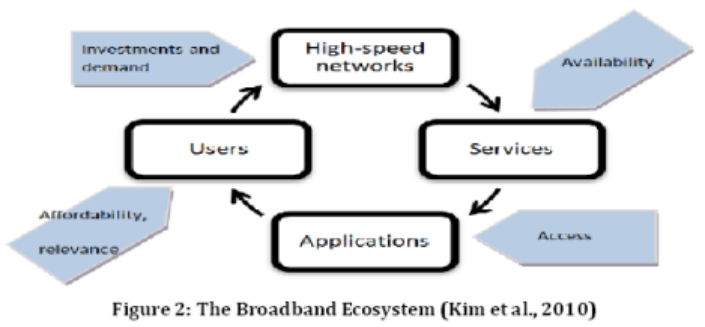

Fig. 2. The Broadband Ecosystem (Kim et al., 2010)

It is important to point out that to facilitate an end-to-end communication service, different network elements, processes and business services need to be present, as illustrated by William (2008) in his layered broadband supply chain model (see Figure 3). At the top of his supply chain are the international connectivity links, usually provided via submarine fibre-optic or satellite links. The second level is the regional and domestic backbone, allowing traffic to flow both domestically and between the international links. The third level represents the routing and switching or the so-called 'intelligence' in the network. Below this is the typical customer network access. Finally, there is the layer of 'soft' retail services such as customer acquisition, customer care and billing.

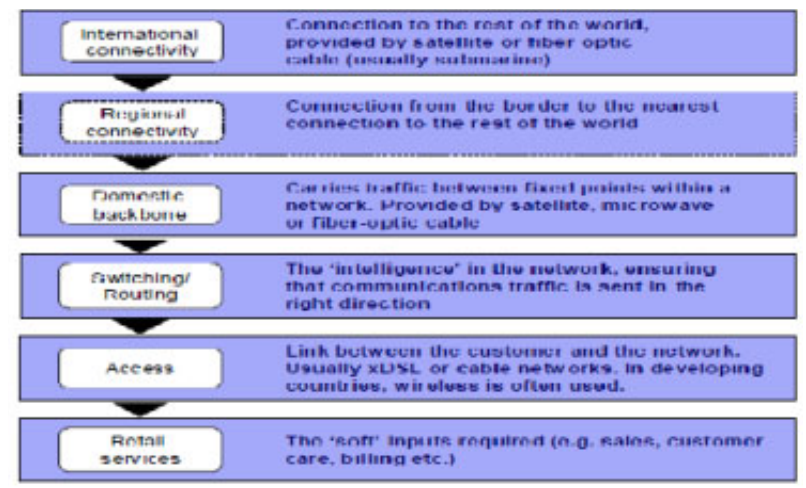

Fig. 3. The Broadband Commuications Supply Chain (Williams, 2008)

\subsection{Socio-economic Impact of Broadband}

Pickot \& Wernick (2007) stress that the economic relevance and societal importance of broadband is becoming more important, due to the diffusion of broadband Internet 
infrastructure reshaping the traditional ICT landscape. According to Kim et al (2010), broadband is a technological innovation that will immensely change people's lives and day-to-day activities, thus enabling economic development and national competitiveness.

There are various positive socio-economic benefits that broadband can deliver, but it is important to note that 'broadband connectivity is a means and not an end in itself' (Jones \& Scott, 2009). Substantial research has been done to show that broadband can play a crucial role in productivity, job creation, innovation, entrepreneurial activities, health, education, e-governance, political activities and personal relations (World Bank, 2009; Katz \& Avila, 2010; Jones \& Scott, 2009; The Broadband Commission, 2010; Willson, Marshall, Young \& McCann, 2009; Srivastava, 2008; Firth \& Mellor, 2005; Horrigan, 2009).

\subsection{Broadband Policy}

Katz \& Avila (2010) found that the formulation of policy is determined by the overarching government vision, and as such impacts on the development of broadband. They note that institutional strength and platform-based competition, and not so much the independence of the regulator, appear to be the most important variables driving broadband innovation and development in a country. In order to implement broadband development strategies, a number of policies, regulations and programmes need to be implemented (Kim et al, 2010).

Policy leadership and political will in government are crucial for the deployment of broadband networks and, most importantly, for the enhancement of local content and skills. Developing countries, conscious of the widening digital divide and the risk that some groups may be missing the economic and social benefits that broadband access promises, are eager to stimulate and promote the uptake of broadband (Kim et al, 2010; The Broadband Commission, 2010; Jones \& Scott, 2009). This, as outlined in Kim et al (2010), can be done by adhering to the good practices that have emerged from countries with advanced broadband markets, such as being visionary and flexible, using competition to promote market growth and facilitating demand.

\section{South African Broadband Environment}

To appreciate the dynamics of media discourse on broadband policy, it is important to take cognisance of the roles and responsibilities of various entities and the activities of various operators in the broadband domain.

\subsection{Actors and Participation}

The major players in the South African broadband arena include state agencies, stateowned enterprises, incumbent operators, Internet Service Providers (ISPs) and resellers. Disappointingly, the role of civil society organisations is limited and thus insignificant. Comninos, Esselaar, Gillwald, Moyo \& Naidoo (2010) note that, in South Africa, the state is still a significant player in the communications sector with full ownership of some enterprises and direct shareholding in major operators like 
Telkom (the incumbent telecommunication provider) and Vodacom (the leading mobile operator).

Communication-related state agencies - which include the Department of Communication (DoC), the Independent Communications Authority of South Africa (ICASA) and the Universal Service and Access Agency of South Africa (USAASA) have a function of formulating policy, regulating the industry and playing an advisory role. Their main responsibility is to create a vibrant ICT sector that will enable all citizens to have access to affordable ICT services, so as achieve socio-economic development goals and to fight the scourge of poverty.

State-owned enterprises, with an interest in communications, are Infraco and Sentech. Infraco is a broadband infrastructure company that was created to intervene in the broadband market and bring down the cost of communicating. Prior to its inception, Telkom was the only company providing national and international broadband backbone access; it was charging Internet service providers and other telecommunications service providers rates far exceeding those seen in other countries. Sentech, a signal distributor and broadcasting network operator, was the first in South Africa to provide wireless broadband service (BMI-T, 2010).

The role played by the civil society was found to be of a less 'formal' nature. Other than minimal contributions from blogs and some civil organisations such as the South African National Broadband Forum (SANBF) and the Association for Progressive Communications (APC), there was no direct contribution from members of the public (see Table 1). The SANBF was the most active civic group, although it became dormant after the draft of the policy was released.

\subsection{Access and Infrastructure}

The commissioning of the SEACOM high capacity bandwidth undersea cable, linking Southern and East Africa to Europe and Asia, attracted considerable media interest. The added backhaul capacity is invaluable but, as in many other developing countries, the problem of the 'last mile' is the true issue at hand in the South African context. Goldstuck (2010) claims that current and future undersea cable projects (like SEACOM) will have a positive impact on accessibility.

Until recently, Telkom held the monopoly in providing urban fibre capacity. With the licensing of Neotel and with the backing of its parent company Tata, about ZAR 10 billion was committed to building a new fibre network. Also, during this time, another key infrastructure player, Dark Fibre Africa (DFK), entered the market (Goldstuck, 2010).

\subsection{Policy Formulation Process, Events and Discourse}

With issues surrounding accessibility and infrastructure arising, the South African Government engaged in sporadic exercises to formulate the National Broadband Policy (see Table 1 for the timelines). Reviewing government's early involvement with driving the Broadband Policy process, there is a noticeable 28-month gap in action. The earliest documents referring to a National Broadband Policy are in those of the Department of Communications Strategic Plan for 2005 to 2008. Following this are regular mentions of a Broadband Policy in Budget Vote speeches in 2005 and 
2006. A final mention is made to it in a speech at the Government Technology Conference in November 2006. Only in March 2009 is mention made again of the Broadband Policy, this time in the 2009/2010 Budget Vote Speech for the Department of Communications.

During 2007, the academic community in South Africa brought broadband back on the agenda, through a special issue of the Southern African Journal of Information and Communication (SAJIC) dedicated to this theme (SAJIC, 2007).

The first mention of a South African Broadband Strategy was found in a blog by Willie Currie (Currie, 2008), although prior to this time mention was only made to Broadband Policy, not strategy. The formation of the South African National Broadband Forum (SANBF) during early 2009 was the next significant event that mobilised support to engage with government and get broadband back on the agenda. After the appointment of a new Minister of Communications in 2009, events moved swiftly towards the publishing of a Draft Broadband Policy in September of 2009.

Table 1. Time-line of Key South African Broadband Policy Events

\begin{tabular}{|c|c|}
\hline Date & \\
\hline 5 Apr 2005 & 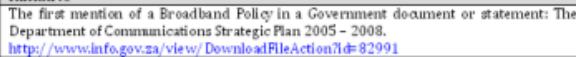 \\
\hline 3 Nov 2006 & 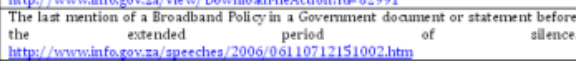 \\
\hline 2007 & 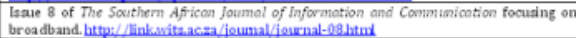 \\
\hline 26 Nov 2008 & 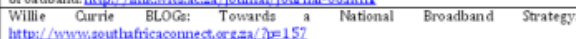 \\
\hline 26 Mar 2009 & 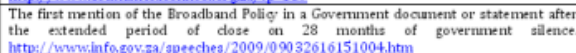 \\
\hline $24 \operatorname{Mar} 2009$ & $\begin{array}{l}\text { A forum is convened by The Assodiation for Progresdive Communications (APC), along } \\
\text { with South Africa Connect. Sangonet and The Shuttleworth Foundation to formulate a } \\
\text { naticnal broadband strategy. }\end{array}$ \\
\hline 6April 2009 & 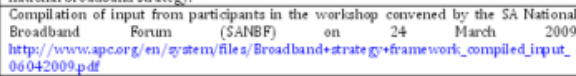 \\
\hline $15 \mathrm{Apr} 2009$ & 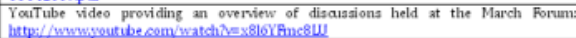 \\
\hline Apr 2009 & $\begin{array}{l}\text { a Framework for a Comprehensive National Eroadband Strategy in } \\
\text { wwwbroadbandtavica ore }\end{array}$ \\
\hline May 2009 & ointed as connumications minister \\
\hline & peech. \\
\hline & $\begin{array}{l}\text { ae } 15.000 \mathrm{~km} \text { undersea fibre-optic cable be gan operationa, providing Djibouti } \\
\text { a. Tanzania. Kenya. Uganda and Mosambique, with high speed lntemet } \\
\text { at to Europe and Asia. }\end{array}$ \\
\hline Aug 2009 & $\begin{array}{l}\text { partment of Communication }\left(\mathrm{D}_{\mathrm{C}} \mathrm{C}\right) \text { signifying a dange in } \\
\text { thy. }\end{array}$ \\
\hline & he post of $\mathrm{D}$ \\
\hline $15 \mathrm{se}$ & 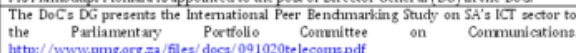 \\
\hline $18 \operatorname{Sep} 2009$ & 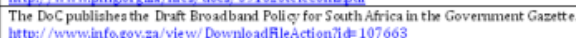 \\
\hline 180 ct 2009 & \begin{tabular}{|l} 
Deadline for written submissions to the DoC on the proposed Draft Broadband Policy. \\
.
\end{tabular} \\
\hline $\begin{array}{l}18-19 \quad \text { Nov } \\
2009\end{array}$ & 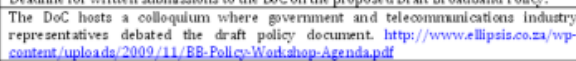 \\
\hline 11 Mar 2010 & $\begin{array}{l}\text { A govermment spokesperson announces that Cabinet has established an linter-Ministerial } \\
\text { Committee to finalise the Draft National Broadband Pollicy for South Africa. The } \\
\text { conmittee will consist of the ministers of Sdence and Technology; Public Enterprise } \\
\text { Rural Development and Land Affairs; Bconomic Development; and Public Service and } \\
\text { Adminiatration. (Vecchiatto, 2010) }\end{array}$ \\
\hline 2010 & $\begin{array}{l}\text { The minister of commumications announces in his budget apeech that the Broadband } \\
\text { Policy has been finalized for implementafion. (Nw anda. 2010) }\end{array}$ \\
\hline 2010 & 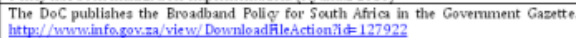 \\
\hline 31 & $\begin{array}{l}\text { We Nyanda is replaced by former deputy conmunications miniater } \\
\text { he new deputy minister is Mr. Obed Bapelz. }\end{array}$ \\
\hline
\end{tabular}

\section{Theoretical Framework}

This section highlights the theoretical framework used and motivates the choice of the critical epistemology and, in particular, the choice of CDA as the research strategy. 
Habermas' Theory of Communicative Action (TCA) is introduced and a method of using it in practice is discussed.

\subsection{Habermas' Discourses and Theory of Communicative Action}

The use of critical research in Information Systems (IS) is recognised as the third research approach besides positivist and interpretivist research; it is defined by critical intention and critical topics (Stahl, 2008).

Habermas places discourse in the centre of his theoretical writing. Habermas' Theory of Communicative Action (TCA) argues that our ability to jointly coordinate our actions using language and communication is a fundamental feature of humans that distinguishes us from all other species (Mingers, 2009). This ability to communicate is grounded in our capacity to understand one another.

Habermas' TCA helps to explain rationality and is based on the anthropological assumption that, as human beings, we require social interaction to survive and thrive. As such, the role of communication is to facilitate cooperation. During the process of communication, each statement or expression is associated with certain validity claims. These validity claims are discussed below and are categorised by Chigona $\&$ Chigona (2008) in Table 2.

Table 2. Summary of Validity Claims (Chigona \& Chigona, 2008)

\begin{tabular}{|c|c|c|c|}
\hline Competence & World & Claim & Explanation \\
\hline Linguistie & & Comprebensibility & $\begin{array}{l}\text { Utterance should be elear in terms of } \\
\text { syntax and semantics. }\end{array}$ \\
\hline \multirow[t]{3}{*}{ Communication } & Objective & Truth & $\begin{array}{l}\text { Utterance should match what the case is } \\
\text { in reality. }\end{array}$ \\
\hline & Subjective & Sincerity & $\begin{array}{l}\text { Checks the intentions of the speaker. } \\
\text { Cannot be observed, ean only be inferred. }\end{array}$ \\
\hline & Social & Legitimisation & $\begin{array}{l}\text { Utterance should be in aceordanee with } \\
\text { soeially aceepted norms. }\end{array}$ \\
\hline
\end{tabular}

- Comprehensibility (C) addresses the technical, syntactical and semantic clarity of the communication. Essentially, it is a qualification that what is being communicated is intelligible, audible or legible.

- Truth (T) validity claim looks for falsehoods and bias interpretations in the texts. It requires that the corpus is examined in a contextualised situation and examines utterances against the Objective (real) World and, as such, requires a comprehensive understanding of the context in which the statements are presented (Chigona \& Chigona, 2008).

- Sincerity (S) looks to see whether what is being communicated is consistent with what is meant and forms the basis of the claim. Sincerity can only be inferred; examining the actions of the speaker and how a message is communicated needs to be compared to what is being said (Chigona \& Chigona, 2008).

- Legitimacy (L) covers the question as to whether the communication conforms to the social environment where it is being delivered. It considers who is silenced and who is considered an expert and evaluates if there is a balance in the communication (Chigona \& Chigona, 2008). 


\subsection{Operationalising Habermasian CDA}

Cukier, Hodson \& Ryan (2009a) recommend a four-step approach for conducting analysis of the data associated with a discourse under review:

Step 1: Defining the corpus to be analysed - Multiple data sources should be used to facilitate being able to gather all relevant material that will explain the situation or artefact under consideration.

Step 2: Analysing the content and doing the coding - The analysis is done for each document within the corpus and also over the full set. This is done to find empirical evidence pertaining to the various validity claims that may be supported or validated.

Step 3: Reading and interpreting the empirical evidence from Step 2 - The documents are now re-read to uncover and test both implied and explicit validity claims. The test involves searching for imperial observations that contradict the validity claims made in the texts.

Step 4: Explaining the findings - This explores and explains the findings in the context of the broader environment of the study area.

\section{Methodology}

The logical starting point to gather the information about the National Broadband Policy is to examine the original documents and statements from Government or political parties. Government statements or press releases related to the National Broadband Policy, as well as speeches by ministers or deputies that referred to the Broadband Policy, were retrieved. Both print and electronic media that had contributed to the broadband debate were included in the corpus. Moreover, a number of well-established web-based IT publications and focused news forums exist and their articles were also included in the corpus. In total, 112 media articles consisting of 24 items from the traditional print media domain and 88 from specialist or other web media sites were identified for analysis.

A number of specialist websites were also identified; these were either specifically dedicated to the National Broadband Strategy or were concerned with general ICT issues in South Africa. These sites are typically maintained by civil society organisations or interest groups and did not yield information that contributed directly to the formal corpus of media articles under review in this paper; however, their activity was deemed an important indicator to the health of public discourse on broadband policy in South Africa.

The various articles were printed and chronologically ordered and put in a binder to enable easy access and to facilitate the reading of all the material in a chronological order. The electronic versions of the articles were uploaded into the Computer Assisted Qualitative Data Analysis System, Nvivo 8. Then the validity claims were tested against the rest of the corpus. 


\section{Findings}

\subsection{Comprehensibility}

As the corpus consisted of material from both the general press and more technicallyfocused publications, it was to be expected that a considerable amounts of industryspecific language or jargon would be present. However, these technical terms are well understood by the industry professionals that the publications are intended for and, as such, do not need further clarification.

\subsection{Truths}

The government, in a bid to frame the draft and the final Broadband Policy for the media, made assertions that broadband would provide multimedia, e-governance, ecommerce, e-health, e-education and many others. These positive claims were similar to the ones that were made in articles that dealt with the policy. Negative claims were also made regarding issues such as the lack of consultative process, lack of clear deliverables in broadband policy, financial constraints, lack of education and awareness.

The media discourse clearly points to the need for a broadband policy, by highlighting the failure of government's managed liberalisation in the telecommunications sector. The SANBF articulates that:

The NBF feels government's efforts have failed, as issues of limited competition and the high cost of services still remain. The solution, it says, lies in the creation of a comprehensive national broadband policy which will help it deal effectively with broadband extension. [ITWeb]

The SANBF further clarifies what it believes to be the main benefits to be derived from an effective broadband policy, placing emphasis on the educational possibilities offered by broadband:

... high-speed broadband access will in turn stimulate the creation of commerce and digital broadband content by content providers, such as educators, so that Government's mandate of affordable learning and teaching can be fully realised. [MyBB]

Quickly, it (the discourse) moves on to bring to the limelight the main benefits that can be derived from an effective Broadband Policy. However, the emphasis on the ability of broadband to facilitate the improvement of education is lost in the overriding e-government rhetoric framing the Broadband Policy view from government. While one of governments espoused benefits of broadband does include e-education, the focus of government's drive for broadband seems to be more on egovernment and economic benefits to be derived from broadband availability.

One of the most glaring omissions from the Broadband Policy discourse by the Department of Communications is that of cost and actual information about implementation. Although it could be argued that such items are to be addressed outside of the policy document, for example in a detailed implementation strategy, this is never made clear, hence leaving many unanswered questions in the mind of the observer, which ultimately could lead to doubt in the policy as a whole. It led an IT publication, ITWeb, to conclude: 
No financial strategy has yet been provided to meet the objective, but the policy does mention that government will use state-owned enterprises, such as Sentech and Infraco, for the provisioning of electronic communications network services. The biggest challenges will be that of actual implementation ... [ITWeb]

Furthermore, one assumption that is not adequately explored in the discourse is whether government departments are indeed ready for e-government. There are no questions raised about whether government IT departments have been integrated into an e-government environment, or whether departments are ready to offer e-services and e-transactions, or if government officials are ready to deliver and support egovernment services to the public. One of the few statements in the discourse on this matter is by Minister Nyanda when he alludes to the probability that government departments are, indeed, not ready, as he urges the adoption of ICT:

Therefore, the development of a coherent framework for the deployment and utilisation of ICT in government is critical. It is urgent that the government adopts and uses ICT in order to modernise services, improve administration and efficiency. [ServPub]

\subsection{Sincerity}

There is some evidence of hyperbole, metaphor and connotative language to reinforce certain perspectives in the discourse and, most importantly, to elicit an emotive response. The most prominent of these are the use of terms like 'digital divide', 'bridging' of this divide, or 'being on the wrong side' of the divide. There are also examples where disappointment and frustration about certain aspects or aspirations come to the fore e.g. the feeling of mediocrity or the lack of ambition:

... aims to provide all citizens with a 256 Kbps connection by 2019. This lacklustre (sic) goal from Government is falling well behind other similar projects. [MyBB]

In addition, South Africa was at times compared with more economically advanced nations, in respect of broadband penetration or broadband access speeds. This has the potential to elicit an emotional response of inferiority and triggers the expectation that the Broadband Policy should be able to get South Africa on a par with these leaders. Most often, these links with advanced economies serve to illustrate how far behind South Africa is to the developed world and implies that having a Broadband Policy would facilitate a way for South Africa to close the gap. Generally, the discourse elicits a response of technological inferiority and the need to catch up.

\subsection{Legitimacy}

The overriding contributor to the discourse is the Department of Communications through statements by the minister, his deputy and director-general. The next dominant voice in the discourse is that of market analysts, most notable those of BMITechKnowledge Managing Director Denis Smit with 11 articles quoting him, while World Wide Worx Managing Director, Arthur Goldstuck and Steve Ambrose had seven articles reflecting their views. As 'experts' and 'neutral bystanders', their views often provided the only alternative non-governmental insights into the discourse.

The civil society in general is not at all well represented in the discourse, primarily because even news publications did not carry stories on the Broadband Policy. 
The SANBF initially had a strong voice in the discourse with a total of 12 articles, but it fell silent after the Draft Broadband Policy was announced in September 2009. Although substantial press coverage was given to the SANBF's website and the partners responsible for its launch, it is surprising that, after the government's publication of the Draft and Final Broadband Policy, there was no ongoing dialogue via this website or any statements of endorsement or rejection. As a result the Broadband Policy was formulated through a closed and non-transparent process; public participation was only 'symbolic'. Public participation does not only ensure success and effectiveness of the policy formulation process, but it also creates ownership of the policy amongst the civil society (Kendall et al, 2006; Barnes, 2006; Mohamed, 2006).

State owned enterprises (SOEs) are also silent on the specifics of the policy. References are made to Sentech and Infraco, but no representation from these entities in the discourse ever touches on the actual Broadband Policy. Surprisingly, these are the institutions which are expected to play a crucial role in order for the policy to be successfully implemented. It is even more worrying that they are not represented in the debate. Nevertheless, it can be argued that the lack of leadership and clear direction at the state entities and state-owned enterprises are the reasons they are not engaged with the media on this matter. Lastly, there was also no input from any of the major broadband providers such as Telkom, Vodacom, MTN or Cell C.

\section{Discussion}

The general atmosphere of the broadband discourse under review is that of 'technooptimism', the 'technology imperative' and 'technological determinism'. Roode et al. (2004) note how technological optimism relates to the belief that developmental problems can be resolved by the availability of, and access to, ICTs. According to Wilson (2002), the technology imperative or technological determinism discounts the fact that information or knowledge do not necessarily have to be associated with ICTs. While ICTs may provide a conduit to accessing certain types of information, or to gain certain knowledge, this is not necessarily the only way.

Generally, in the discourse, the Broadband Policy does not appear to feature prominently in the collective minds of the general public. The government ignored the fact that effective policies can only be achieved through outlining clear and possible goals that will be achieved by the policy improvements and, most importantly, by appealing to societal interests - no power can ever be exercised without consent and interest from the civil society (Boswell, 2009). Most policies in developing countries, even in developed nations, meet resistance due to the lack of instrumental participation on the part of civil society in the development of these policies (Hideg et al, 2011). Moreover, an inclusive policy formulation process which involves all actors, even latent ones, other than civil society, does not only create the effectiveness of the policy, but it goes to the extent of creating its ownership (Hicks \& Buccus, 2007; Sack \& Marope, 2007). The case in point in this research is the nonparticipation of the private sector which may have a negative impact on the policy outcomes. 
It can be argued that the policy has the potential to significantly improve people's lives and wellbeing, but currently the development of a Broadband Policy is secondary to more pressing issues such as basic services provision. Issues that directly affect people's quality of life inevitably take precedence. One reason for this poor public engagement is perhaps related to the way that the non-ICT focused media reported on the Broadband Policy. These sources closely followed the press releases from government, but rarely added substantial commentary to the statements. This is in line with the findings of Quail \& Larabie (2010) that the poor coverage of the topic 'does not lend itself to a critically informed and engaged public'. Moreover, the withdrawal of civil society groups such as the SANBF was also a cause for serious concern - lobbyists and pressure groups are members of the public sphere and are essential for maintaining and evolving a democratic society (Cukier et al, 2009b).

During the period under review, there was a notable change in the discourse from optimism to a less favourable, pessimistic outlook. The importance of following this mood change in the discourse is that the policy is inextricably linked to the DoC and its senior officials e.g. the Minister. As these entities are afforded the custodianship of the Broadband Policy, the observer's feelings about the policy become entangled with feelings about the custodian. A brief review of activities at the department and the general resultant turmoil, lead to the conclusion that the Broadband Policy gets affected by these events. Some events and signs of disarray are shown in Table 3 . As Gillwald (2010) pointed out, it is necessary to recognise the political dimensions of policy reform and to examine the interaction of the state and the market if we are to understand the general failure of ICT policy outcomes in Africa.

Table 3. Time-line of key events at the DoC

\begin{tabular}{|c|c|}
\hline Date & Event \\
\hline May 2009 & $\begin{array}{l}\text { Retired General Siphiwe Nyanda is appoirted as communications minister with as de puty } \\
\text { minister Ms Dina Pule. }\end{array}$ \\
\hline Aug 2009 & Ms Mamodupi Mohlala is appointed to the post of Director General (DG) in the DoC. \\
\hline Oet 2009 & $\begin{array}{l}\text { The DoCs head of Human Resources (HR), Ms Basani Baloyi is reinstated after an earlier } \\
\text { suspension on disciplinary charges }\end{array}$ \\
\hline Nov 2009 & Ms Basani Baloyi is suspende d a gain. \\
\hline Oct 2009 & Deadline for written submiscions to the DoC on the proposed Draft Broadband Policy. \\
\hline Iuly 2010 & Minister Nyand a suap ends the DG, Mamodupi Mohlala. \\
\hline Aug 2010 & Dr Harold Wesso is appointed acting DG. \\
\hline Oet 2010 & Ma Mohlala leaves the DoC \\
\hline Oct 2010 & $\begin{array}{l}\text { Retired General Siphiwe Ny anda is replaced by former deputy communications minister } \\
\text { Roy Padayadie and the new de puty minizter is Mr. Obed Bapela. }\end{array}$ \\
\hline
\end{tabular}

One important question that emanates from these events is how an entity, with this level of instability and upheaval and with apparent lack of continuity in its leadership structure, can function. As the Broadband Policy is so closely linked and associated with the DoC, it is hard not to project the negative sentiments about the department onto the policy. To make matters worse, throughout the discourse there are repeated references to not only the DoC being in a state of crisis, but also to the unrest in associated and crucial state entities, like ICASA, USAASA, Sentech and Infraco - the very entities that are supposed to implement the policy. In the same way that one 
would associate the policy with the custodians, one would also associate the policy with the implementers.

Furthermore, the exclusion of large local corporate broadband providers raised concerns about the prevailing uncoordinated efforts. The ability of the SOE's to deliver on the Broadband Policy objective was questionable and therefore allowed private enterprises to continue to follow their own agendas. Finally, although international best practice seems to suggest that policy is needed, this clearly needs to be balanced by action. So far, the feeling created in the discourse is that the Broadband Policy is 'lip service' and that it 'ticks the boxes'. There is no optimism that it will make a real difference to the citizens of the country.

\section{Conclusion}

The analysis revealed that the association and disassociation of various role players in the South African broadband environment has created a negative perception around the Broadband Policy. Although the government's rhetoric on the Broadband Policy is of a positive nature, the constant linking of the policy to reporting on negative industrial and political aspects ultimately influences the perception about the policy and the ability for the policy to be implemented.

This study has contributed to the body of knowledge about the formulation of ICT Policy and Broadband Policy in the context of a developing country. Moreover, some contribution was made to unravelling the complexities of the political and regulatory aspects in the South African telecommunications environment, although this is an area where further ongoing research is needed.

Considering the generalizability of this research (Lee \& Baskerville, 2003), the theoretical contributions of this paper to understanding media involvement in ICT and Broadband Policy formulation may be of value in other settings, or when considering other policy formulation processes. Most developing countries have similar, if not the same, institutions and, most importantly, they also have similar ways of doing things. Therefore, on a practical note, the results and lessons extracted from this study can be used to understand the 'noise' that surrounds policy formulation processes in developing countries and hence the failure of many policies. Furthermore, the contributions of this paper also bring to the limelight the importance of government institutions, in the sense that poor government institutions result in poor policies and outcomes. Weak institutions beget a state that fails to deliver on its promises and a sceptical private sector and civil society that lacks confidence in any government process or intervention.

The paper recommends that for governments of developing countries to have effective policies that will be owned by the masses, these governments need to start viewing civil society as a partner in policy-formulation exercises. Civil society can only be equipped to partake in such activities if there is a vibrant and an encouraged media that is willing to educate the population on emerging technologies and policies. Finally, governments should strengthen state institutions that are involved in the telecommunications sector so that benefits of broadband or any development-related technologies are clear and well appreciated. 


\section{References}

Barnes, T.: Nation-Building without Mortar? Public Participation in Higher Education PolicyMaking in South Africa. Research Article. Perspectives in Education 24(1), 1-14 (2006)

BMI-T. SA Wireless Access and Broadband Market. Business Monitor International TechKnowledge Group (October 2010)

Boswell, C.: Knowledge, legitimation and the politics of risk: the functions of research in public debates on migration. Political Studies 57, 165-186 (2009)

Chigona, A., Chigona, W.: MXit up in the media: media discourse analysis on a mobile instant messaging system. The Southern African Journal of Information and Communication 9(0), 42-57 (2008)

Comninos, A., Esselaar, S., Alison Gillwald, A., Moyo, M., Naidoo, K.: South African ICT Sector Performance Review 2009/2010. Research ICT Africa (2010),

http: / / www. researchictafrica.net/new/images/uploads /

SPR20092010/SA_SPR-final-web_Master_130ct.pdf

(retrieved November 28, 2010)

Cooper, C.A., Johnson, M.: News Media and State Policy Process: Perspectives from Legislators and Political Professionals, State Politics and Policy Conference. University of Texas, Austin (February 22-24, 2007)

Cukier, W., Hodson, J., Ryan, P.M.: A Critical Discourse Analysis of Amazon.com's Rise in the Media 1995-2008. In: World Congress on Privacy, Security, Trust and the Management of e-Business, pp. 1-10, 25-27 (2009a)

Cukier, W., Ngwenyama, O., Bauer, R., Middleton, C.: A Critical Analysis of Media Discourse on Information Technology: preliminary results of a proposed method for critical discourse analysis. Information Systems Journal 18(2), 175-196 (2009b)

Currie, W.: Towards a National Broadband Strategy (2008),

http://www.southafricaconnect.org.za/?p=157 (retrieved November 8, 2010)

Delano, R.: The globalisation of ICT. Black Business Quarterly 30(7), 40-41 (2009)

Department of Communications (DoC). (n.d.). About the DoC, http://www.doc.gov.za/index.php?option=com_content\&view= article\&id=428\&Itemid=505 (retrieved November 28, 2010)

Department of Communications (DoC). Broadband Policy for South Africa (2010), http: / / www.info.gov.za/view/DownloadFileAction?id=127922 (retrieved November 19, 2010)

Firth, L., Mellor, D.: Broadband: benefits and problems. Telecommunications Policy 29, 223 $236(2005)$

Gillwald, A.: The Poverty of ICT Policy, Research, and Practice in Africa (2010), http://itidjournal.org/itid/article/viewFile/628/268 (retrieved December 5, 2010)

Goldstuck, A.: Internet Access in South Africa 2010 - A Comprehensive Study of the Internet Access Market in South Africa. World Wide Worx (2010)

Guardino, M.: Media Discourse, Public Policy and Democracy: A Preliminary Case Study of the Reagan Tax and Budget Plans of 1981 (2009), http: / / jpm.syr.edu/pdf / fellowpdfs/31_a.pdf (retrieved December 11, 2010)

Habermas, J.: The Theory of Communicative Action. Beacon Press, Boston (1984) 
Hideg, I., Michela, J.L., Ferris, D.L.: Overcoming negative reactions of nonbeneficiaries to employment equity: The effect of participation in policy formulation. Journal of Applied Psychology 96(2), 363-376 (2011)

Hicks, J., Buccus, I.: Crafting new democratic spaces: participatory policy-making in KwaZulu-Natal, South Africa. Transformation 23(65), 94-119 (2007)

Horrigan, J.: Home Broadband Adoption 2009. Pew Internet \& American Life Project (2009), http: / /www. pewInternet.org/ /media//Files/Reports / 2009 /HomeBroadband-Adoption-2009.pdf (retrieved September 13, 2009)

Jones, D., Scott, M.: Creating successful broadband policies in developing countries. Research Report - Analysys Mason (2009)

Katz, R.L., Avila, J.G.: The impact of broadband policy on the economy. In: Proceedings of the 4th ACORN-REDECOM Conference, Brasilia (May 14-15, 2010)

Kendall, K.E., Kendall, J.E., Kah, M.M.O.: Formulating information and communication policy through discourse: how internet discussions shape policies on ICTs for developing countries. Information Technology for Development 12(1), 25-43 (2006)

Kim, Y., Kelly, T., Raja, S.: Building broadband: Strategies and policies for the developing world. Global Information and Communication Technologies (GICT) Department, World Bank (2010), http://www. infodev.org/en/Document.756.pdf (retrieved November 5, 2010)

Lee, A.S., Baskerville, R.L.: Generalizing generalizability in information systems research. Information Systems Research 14(3), 221-243 (2003)

McBride, N., Stahl, B.C.: Egypt's Information Society Strategy: A Critical Lexicography. Journal of International Technology and Information Management 18(1) (2009)

Melody, W.H.: Policy implications of the new information Economy (2006), http://lirne.net/resources/papers/ToolBook-NIE.pdf (retrieved December 11, 2010)

Mills, R.: The Effect of Legislative Professionalism on Agenda Setting at the State Level. Conference Papers - Midwestern Political Science Association, p. 1 (2009)

Mingers, J.: Discourse Ethics and Critical Realist Ethics: An Evaluation in the Context of Business. Journal of Critical Realism 8(2), 172-202 (2009)

Mohamed, S.E.: From ideas to practice: The involvement of informal settlement communities in policy-making at city level in South Africa. South African Review of Sociology 37(1), 35-47 (2006)

Norton-Griffiths, M.: The growing involvement of foreign NGOs in setting policy agendas and political decision-making in Africa. Economic Affairs 30(3), 29-34 (2010)

Nyanda, S.: Minister of Communications S. Nyanda Budget Vote speech - ICT for accelerated service delivery and empowerment! (April 20, 2010),

http: //www . info.gov.za/speech/DynamicAction?pageid= 461\&sid=9573\&tid=9590 (retrieved August 8, 2010)

Pickot, A., Wernick, C.: The role of government in broadband access. Telecommunications Policy 31(10-11), 660-674 (2007)

Quail, C., Larabie, C.: Net Neutrality: Media Discourses and Public Perception. Global Media Journal - Canadian Edition 3(1), 31-50 (2010),

http: / / www.gmj . uottawa.ca/1001/v3i1_quail\%20and\%201arabie.pdf (retrieved December 11, 2010)

Roode, D., Speight, H., Pollock, M., Webber, R.: It's Not The Digital Divide - It's The SocioTechno Divide! Presentation to the 12th European Conference on Information Systems, Turku (June 14, 2004) 
Sack, R., Marope, M.: The Pedagogy of Education Policy Formulation: Working from Policy Assets. Perspectives in Education 25(1), 11-30 (2007)

SAJIC. The Southern African Journal of Information and Communication. Issue 8 (2007), http://www.sajic.org.za/index.php/SAJIC/issue/view/32 (retrieved December 19, 2010)

Srivastava, A.: Broadband for Health in Developing Countries. Handbook of Research on Global Diffusion of Broadband Data Transmission (2008)

Stahl, B.C.: The ethical nature of critical research in information systems. Information Systems Journal, Special Issue on Exploring the Critical Agenda in IS Research, edited by Brooke, C., Cecez-Kecmanovic, D., Klein, H.K., 137-163 (2008)

The Broadband Commission. A 2010 Leadership Imperative: The future built on broadband (2010a), http://www.broadbandcommission.org/report1.pdf (retrieved November 19, 2010)

The Broadband Commission. Broadband: A platform for progress (2010b), http: / / www . broadbandcommission. org/report2 .pdf (retrieved November 19, 2010)

The Broadband Forum (n.d.). Call for a Comprehensive National Broadband Strategy for South Africa, http: / / www. broadband4africa.org. za (retrieved May 2, 2010)

Thompson, M.P.A., Walsham, G.: ICT research in Africa: a need for a strategic developmental focus. Working Paper Series edn. Judge Business School, University of Cambridge (2010)

Van den Broeck, W., Lievens, B.: Why Broadband? The meaning of broadband for residential users. South African Journal of Information and Communication 8, 30-52 (2007)

Williams, M.: Broadband for Africa - Policy for promoting the development of backbone networks. infoDev, The World Bank (2008)

Willson, P., Marshall, P., Young, J., McCann, J.: Evaluating the Economic and Social Impact of the National Broadband Network. In: 20th Australasian Conference on Information Systems, Melbourne, Australia (December 2-4, 2009)

Wilson, M.: Understanding the International ICT and Development Discourse: Assumptions and implications. South African Journal of Information and Communication 3(0) (2002)

World Bank. Information and Communications for Development 2009: Extending Reach and Increasing Impact (2009), http://go.worldbank.org/55ZNQF16N0 (retrieved May 17, 2010) 